\title{
Cell-free synthesis of functional phospholipase A1 from Serratia sp.
}

\author{
Hye Jin Lim ${ }^{1,2}$, Yu Jin Park' , Yeon Jae Jang ${ }^{1}$, Ji Eun Choi ${ }^{2}$, Joon Young Oh², Ji Hyun Park², Jae Kwang Song ${ }^{2 *}$ \\ and Dong-Myung $\mathrm{Kim}^{1 *}$ (D)
}

\begin{abstract}
Background: Phospholipase A1 is an enzyme that hydrolyzes phospholipids at the $s n-1$ position. It has potential applications across diverse fields including food, pharmaceutical, and biofuel industries. Although there has been increasing interest in the use of phospholipase A1 for degumming of plant oils during biodiesel production, production of recombinant phospholipase $\mathrm{A} 1$ has been hampered by low efficiency of gene expression and its toxicity to the host cell.

Results: While expression of phospholipase A1 in Escherichia coli resulted in extremely low productivity associated with inhibition of transformed cell growth, drastically higher production of functional phospholipase A1 was achieved in a cell-free protein synthesis system where enzyme expression is decoupled from cell physiology. Compared with expression in E. coli, cell-free synthesis resulted in an over 1000-fold higher titer of functional phospholipase A1. Cellfree produced phospholipase A1 was also used for successfully degumming crude plant oil.

Conclusions: We demonstrate successful production of Serratia sp. phospholipase A1 in a cell-free protein synthesis system. Including the phospholipase A1 investigated in this study, many industrial enzymes can interfere with the regular physiology of cells, making cellular production of them problematic. With the experimental results presented herewith, we believe that cell-free protein synthesis will provide a viable option for rapid production of important industrial biocatalysts.
\end{abstract}

Keywords: Industrial enzymes, Biodiesel, Phospholipase A1, Cell-free protein synthesis, Enzymatic degumming

\section{Background}

Increasing demand for sustainable energy has accelerated research and development in biodiesel as well as other sectors of the biofuel industry [1]. Crude oils extracted from plants contain a variety of non-triglyceride components, which need to be removed before the oils can be used as feedstock for biodiesel production.

Degumming is a common practice for the removal of phospholipids before vegetable oils are fed into the biodiesel production process [2]. Phospholipid removal is of particular importance during enzymatic biodiesel production because phospholipids substantially inhibit

\footnotetext{
*Correspondence: ajee@krict.re.kr; dmkim@cnu.ac.kr

${ }^{1}$ Department of Chemical Engineering and Applied Chemistry, Chungnam National University, Daejeon 305-764, Republic of Korea ${ }^{2}$ Research Center for Bio-based Chemistry, Korea Research Institute of Chemical Technology, Daejeon 305-600, Republic of Korea
}

enzymatic transesterification reactions and decrease the efficiency of biodiesel separation [3, 4]. While hydratable phospholipids can be readily removed by the simple water degumming process, removal of nonhydratable phospholipids typically requires a chemical refining process that usually consists of sequential acid and alkali treatment steps [5]. The chemical degumming process, however, produces large amounts of soapstock, which causes significant loss of oil during its separation. The use of caustic chemicals also has negative impacts on the environment. In this respect, phospholipase A1 (PLA1)mediated enzymatic degumming to convert nonhydratable phospholipids into hydrophilic lysophospholipids is considered to be a simpler, more efficient and environment-friendly alternative to the chemical processes $[6$, 7]. Although there are a few commercially available PLA1 sources, relatively little effort has been directed toward 
the development of bacterial phospholipases for industrial enzymatic degumming. Because plant oils differ substantially in their composition and phospholipid content, it is highly desirable to have a technological platform to produce and characterize phospholipases from diverse sources.

Unlike the conventional cell-based gene expression methods, cell-free protein synthesis uses protein synthesis machinery in open environments and thus can produce proteins by direct addition of template DNA. Therefore, it offers a much faster and more flexible route to protein production [8]. In addition, cell-free protein synthesis does not require the maintenance of cell viability and integrity of cellular membranes. These unique features make cell-free protein synthesis a potentially ideal platform to produce recombinant enzymes that otherwise would interfere with the normal physiology of host cells.

In this study, the technique of cell-free protein synthesis was applied to the expression of functional phospholipase A1 (PLA1) from Serrartia sp. While significant amounts of recombinant PLA1 were not obtained from liter-scale cultures of Escherichia coli (E. coli) due to substantial inhibition of cell growth and protein biosynthesis, cell-free synthesis reactions at microliter scales produced functional PLA1 in amounts sufficient for subsequent analyses. PLA1 synthesized in the cell-free system was confirmed to be highly functional and successful at degumming crude sesame oil. Furthermore, the cellfree synthesis reaction was proven to be readily scalable, showing constant volumetric productivity when scaledup from $150 \mu \mathrm{L}$ to $500 \mathrm{~mL}$. As expected, when our phospholipase A1 was utilized to degum crude oil, the cloudy oil was converted to clear. These results demonstrate that cell-free synthesis provides a versatile platform for the production of functional phospholipases, and it can be extended to the production of other industrially important enzymes from analytical to preparative scales.

\section{Methods}

\section{Chemicals and enzymes}

Sesame crude oil was purchased from the market (Daejeon, Korea). Luria-Bertani (LB) medium and ampicillin were purchased from Duchefa Biochemie (Haarlem, The Netherlands). Ni-NTA agarose resin was from Qiagen (Hilden, Germany). ATP, GTP, UTP, CTP, and creatine kinase were purchased from Roche Applied Science (Indianapolis, IN). Creatine phosphate was a kind gift from Bioneer Co. (Daejeon, Korea). L-[U- $\left.{ }^{14} \mathrm{C}\right]$ leucine was from Perkin Elmer (Waltham, MA). All other chemical reagents were obtained from Sigma-Aldrich (St Louis, MI) and used without further purification. The S12 extract prepared from the E. coli strain BL21Star (DE3)
(Invitrogen, Carlsbad, CA) was used as a source of protein synthesis machinery as described previously [9].

\section{Expression of Serratia PLA1 in E. coli}

The PLA1 gene was PCR-amplified from genomic DNA of Serratia sp. MK1 [10] and cloned into the pET21a and the pSTV28 plasmids. The resulting plasmids (pET21a Serr PLA1 and pSTV28 Serr PLA1) was transformed into the $E$. coli strain BL21Star (DE3). After overnight incubation of the seed culture in $5 \mathrm{~mL}$ of $\mathrm{LB}, 4 \mathrm{~mL}$ each of the resulting bacterial culture was transferred into $400 \mathrm{~mL}$ of LB medium $(50 \mu \mathrm{g} / \mathrm{mL}$ of ampicillin or $25 \mu \mathrm{g} / \mathrm{mL}$ of chloramphenicol was used as the antibiotic for each transformant) in two $3 \mathrm{~L}$ flasks and grown at $37^{\circ} \mathrm{C}$ with vigorous shaking. Expression of PLA1 was induced with $0.6 \mathrm{mM}$ isopropyl $\beta$-D-1-thiogalactopyranoside (IPTG) when the $\mathrm{OD}_{600}$ of culture broth reached 0.6. Samples were taken throughout the culture period for the assay of expressed enzyme after disruption of the cells by sonication.

\section{Cell-free synthesis of Serratia PLA1}

The plasmid pET21a Serr PLA1 used for E. coli-based expression of Serratia PLA1 was also used as the template for the cell-free protein synthesis reactions. The standard reaction mixture for cell-free synthesis consists of the following components in $150 \mu \mathrm{L}: 57 \mathrm{mM}$ HEPES$\mathrm{KOH}$ (pH 7.5); $1.2 \mathrm{mM}$ ATP; $0.85 \mathrm{mM}$ each of GTP, UTP, and CTP; $80 \mathrm{mM}$ ammonium acetate; $34 \mu \mathrm{g} / \mathrm{mL} 1$-5-formyl-5,6,7,8-tetrahydrofolic acid (folinic acid); $1.0 \mathrm{mM}$ each of the 20 amino acids; $2 \%$ PEG (8000); $3.2 \mathrm{U} / \mathrm{mL}$ of creatine kinase; $67 \mathrm{mM}$ creatine phosphate; $0.01 \mathrm{mM}$ $\mathrm{L}-\left[\mathrm{U}-{ }^{14} \mathrm{C}\right]$ leucine $(11.1 \mathrm{GBq} / \mathrm{mmol}) ; 27 \%(\mathrm{v} / \mathrm{v})$ of the $\mathrm{S} 12$ extract; and $13.0 \mu \mathrm{g} / \mathrm{mL}$ of plasmid. After incubation of the reaction mixture at $37^{\circ} \mathrm{C}$ for $3 \mathrm{~h}$, cell-free synthesized protein was quantified by measuring trichloroacetic acid (TCA)-insoluble radioactivity using a Tri-Carb 2810TR liquid scintillation counter (PerkinElmer, Waltham, MA), as described previously $[8,11]$. Cell-free synthesized proteins were also analyzed on $12 \%$ SDS-PAGE gels. Enzymatic activity of the PLA1 protein produced during cell-free synthesis reactions was determined using EnzChek ${ }^{\circledR}$ Phospholipase $A_{1}$ Assay Kit (Invitrogen, Carlsbad, CA) following the manufacturer's protocols.

\section{Purification of recombinant PLA1}

For purification of the PLA1 expressed in E. coli, cells were harvested from $1 \mathrm{~L}$ of culture broth at $16 \mathrm{~h}$ after the addition of IPTG, washed with $500 \mathrm{~mL}$ of phosphate buffered saline (PBS) and resuspended in $20 \mathrm{~mL}$ of $50 \mathrm{mM}$ sodium phosphate buffer containing $300 \mathrm{mM} \mathrm{NaCl}$ and $10 \mathrm{mM}$ imidazole ( $\mathrm{pH}$ 8.0). The cells were disrupted by sonication on ice. After removing cell debris by centrifugation (10,000 RCF, $15 \mathrm{~min}$ ), the supernatant was mixed 
with a $1 \mathrm{~mL}$ suspension of Ni-NTA agarose resin. After incubation for $30 \mathrm{~min}$ with gentle agitation, the Ni-NTA agarose resin was washed thrice with $100 \mathrm{~mL}$ of buffer A $\left(50 \mathrm{mM} \mathrm{NaH} \mathrm{PO}_{4}, 300 \mathrm{mM} \mathrm{NaCl}, 20 \mathrm{mM}\right.$ imidazole, $\mathrm{pH}$ 8.0). Subsequent to the final wash, bound proteins were eluted with $5 \mathrm{~mL}$ of buffer $\mathrm{E}\left(50 \mathrm{mM} \mathrm{NaH} \mathrm{PO}_{4}\right.$, $300 \mathrm{mM} \mathrm{NaCl}, 250 \mathrm{mM}$ Imidazole, $\mathrm{pH} 8.0$ ) and dialyzed against $1 \mathrm{~L}$ of $10 \mathrm{mM}$ sodium phosphate buffer ( $\mathrm{pH}$ 7.4) at twice. For the purification of cell-free synthesized PLA1, $3 \mathrm{~mL}$ of a completed cell-free synthesis reaction was centrifuged at 10,000 RCF for $15 \mathrm{~min}$ and the supernatant was mixed with $1 \mathrm{~mL}$ suspension of Ni-NTA agarose resin. After incubation for $30 \mathrm{~min}$, the beads were washed thrice with $2 \mathrm{~mL}$ of buffer A. Subsequent to the final wash, bound protein was eluted with $5 \mathrm{~mL}$ of buffer $\mathrm{E}$ and twice dialyzed against $1 \mathrm{~L}$ of $10 \mathrm{mM}$ sodium phosphate buffer (pH 7.4).

\section{Degumming of crude plant oils using cell-free synthesized PLA1}

Ten $\mathrm{mL}$ of crude sesame oil was heated to $60{ }^{\circ} \mathrm{C}$ in a water bath for $1 \mathrm{~h}$ and cooled down to $40{ }^{\circ} \mathrm{C}$. Varying amounts of purified PLA1 was diluted in $0.5 \mathrm{~mL}$ of deionized water and added to the sesame oil. The PLA1 enzyme was dispersed in oil/water emulsion by vortexing (3000 rpm, $1 \mathrm{~min}$ ) the mixture. The degumming reaction was conducted by placing the tube in an incubating shaker set at $300 \mathrm{rpm}$ and $40{ }^{\circ} \mathrm{C}$. After $12 \mathrm{~h}$ of incubation, the degumming reaction was stopped by heating the reaction mixture to $90{ }^{\circ} \mathrm{C}$ for $10 \mathrm{~min} .0 .4 \mathrm{~mL}$ of samples were taken and analyzed using a $\mathrm{Rxi}^{\circledR}-5$ Sil MS column (Restek, Bellefonte, PA) in a GC7890A gas chromatography analyzer (Agilent Technologies, Santa Clara, CA) connected to a $5975 \mathrm{c}$ mass selective detector (MSD). The oven was held at $80{ }^{\circ} \mathrm{C}$ for $2 \mathrm{~min}$, ramped to $140{ }^{\circ} \mathrm{C}$ at a rate of $10{ }^{\circ} \mathrm{C} / \mathrm{min}$, to $240{ }^{\circ} \mathrm{C}$ at a rate of $4{ }^{\circ} \mathrm{C} / \mathrm{min}$, to $300{ }^{\circ} \mathrm{C}$ at a rate of $10{ }^{\circ} \mathrm{C} / \mathrm{min}$, and then held at $300{ }^{\circ} \mathrm{C}$ for $20 \mathrm{~min}$. Helium was used as the carrier gas at a constant flow rate of $1 \mathrm{~mL} / \mathrm{min}$ through the column. As an indicator of degumming products, concentration of linoleic acid was measured using dodecanoic acid as an internal standard [12].

\section{Results and discussion}

\section{E. coli-based expression of recombinant Serratia PLA1}

We previously reported very low expression levels of recombinant Serratia PLA1 in E. coli [13-16]. When the PLA1 gene was expressed under the control of the weak lac promoter on a low copy number plasmid (pSTV28), approximately $100 \mu \mathrm{g}$ of purified PLA1 enzyme was obtained from a $100 \mathrm{~mL}$ culture of transformed E. coli. It should be noted that the expression level of PLA1 was even lower when the same gene was moved to an expression vector containing a strong promoter. For example, when cloned in the pQE70 plasmid under the T5 promoter, less than $30 \mu \mathrm{g}$ of purified PLA1 was obtained from a $100 \mathrm{~mL}$ culture. Although not discussed in the previous reports, this appears to be due to the toxicity of the enzyme to E. coli. Because the T7 promoter used in this study is stronger than the T5 promoter [17-19], we expected that the induction of PLA1 expression would further decrease the yield of PLA1. Indeed, during the cultivation of $E$. coli transformed with the plasmid pET21a Serr PLA1, we found significant growth inhibition after induction with IPTG. A decrease in the growth rate of approximately $25 \%$ was observed in induced $E$. coli as compared to a control culture without IPTG induction (Fig. 1a). Although time-course analysis of PLA1 activity indicated accumulation of functional PLA1 after IPTG induction (Fig. 1b), the expression level was too low to be confirmed by SDS-PAGE and immunoblot analysis (data not shown). We presumed that the onset of PLA1 expression from the strong T7 promoter caused significant damage to the cells and decreased cellular production of proteins. This presumption was confirmed by measuring the amounts of total cellular protein in the E. coli with or without IPTG induction. As shown in Fig. 1c, compared to non-induced E. coli, the IPTGinduced cells had approximately $25 \%$ less total cellular protein.

Maintenance and alteration of lipid asymmetry are deeply involved in the process of cell division. A number of phospholipid-modifying enzymes are responsible for generating asymmetry in the phospholipid composition of the inner and outer leaflets of cell membranes [20]. One such example is the constitutively expressed outer membrane phospholipase A1 found in E. coli and many other gram-negative bacteria [21]. It thus is reasonable to assume that high-level intracellular expression of foreign PLA1 can disturb the balanced asymmetry and deteriorate the integrity of the cell membrane. This assumption is also strengthened by the fact that exogenous PLA1s secreted from pathogenic bacteria, and those found in the venom of bees and snakes, cause destabilization and hemolysis of nearly all kinds of cells [22, 23].

\section{Cell-free synthesis of PLA1}

Based on the assumption that E. coli-based expression of Serratia PLA1 is hampered by the membrane toxicity of the expressed enzyme, we decided to investigate the use of cell-free protein synthesis as an alternative expression platform for this enzyme. Because cell-free protein synthesis reactions do not require the presence of an integral membrane, we expected that the enzymatic activity of the synthesized PLA1 would not inhibit continuous expression of this membrane-disrupting enzyme. For a 

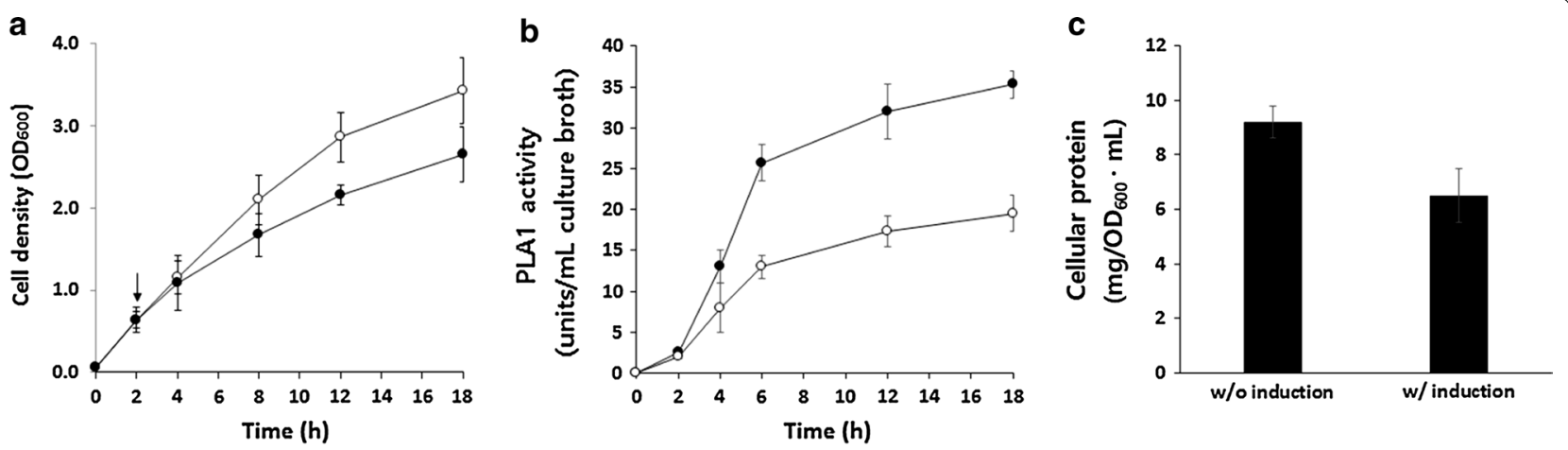

Fig. 1 Expression of recombinant PLA1 in E. coli. Escherichia coli strain BL21 (DE3) was grown in $400 \mathrm{~mL}$ of LB media after being transformed with the plasmid pET21a Serr PLA1. Samples of culture broth were taken throughout the culture period to measure optical density at $600 \mathrm{~nm}$ (a) and PLA1 activity (b) as described in the "Methods" section. At $16 \mathrm{~h}$ after induction with IPTG, the total amount of cellular protein was measured by the BCA assay (c). Arrows indicate the time point for IPTG induction. Results from the E. coli cultures with or without IPTG induction are shown in closed and open circles, respectively. Error bars represent the standard deviation from three independent experiments

direct comparison, the same plasmid used for the E. colibased expression (pET21a Serr PLA1) was expressed in the cell-free synthesis reaction mixture under the conditions described in "Methods" section. In contrast to the results from the cell-based expression, approximately $0.35 \mathrm{mg} / \mathrm{mL}$ of Serratia PLA1 was produced after a $3 \mathrm{~h}$ incubation of the reaction mixture for cell-free synthesis. In addition, approximately $54 \%$ of the synthesized protein was found in the soluble fraction. Figure 2a shows the results of quantitative measurements of the cell-free synthesized PLA1 along with the SDS-PAGE and immunoblot data. The relative advantage of using the cellfree synthesis system is highlighted when the enzymatic activity of PLA1 was normalized to the amount of endogenous cellular proteins in the S12 extract. As presented in Fig. 2b, PLA1 activity per mg of endogenous protein was more than 1000 fold higher in the cell-free synthesis system than when expressed in E. coli. Although PLA1 titer in $E$. coli significantly increased when the expression vector was switched from pET21a (T7 promoter) to pSTV28 (lac promoter), still, normalized enzymatic activity of PLA1 was less than $0.4 \%$ compared to the cell-free synthesis system.

While we failed to obtain meaningful amounts of purified PLA1 from a $1 \mathrm{~L}$ culture of $E$. coli, a clear band of PLA1 was confirmed on the Coomassie blue-stained gel after purification from a $3 \mathrm{~mL}$ cell-free reaction (Fig. 3a). It was estimated that approximately $300 \mu \mathrm{g}$ of purified PLA1 was recovered from the $3 \mathrm{~mL}$ cell-free synthesis reaction (recovery yield $\approx 40 \%$ ). The PLA1 enzyme purified from the $3 \mathrm{~mL}$ of cell-free synthesis reaction was used for degumming of crude sesame oil to test its usability in biodiesel production. As shown in Fig. 3b, incubation with the cell-free synthesized PLA1 cleared the cloudy crude oil, indicating that the recombinant PLA1 successfully catalyzed the degumming reaction. Gas chromatography analysis results also showed an increase in the concentration of linoleic acid in the oil depending on the amount of the used enzyme (Table 1 and Additional file 1: Figure S1).

We next examined whether the reaction volume of cell-free synthesis can be changed without affecting the productivity of functional enzymes. While optimal conditions of heterogeneous cell culture often vary depending on size, the homogenous nature of cell-free protein synthesis reactions results in a more chemistry-like scaleup $[24,25]$. When the reaction volume of the cell-free PLA1 synthesis was sequentially increased from $150 \mu \mathrm{L}$ to $500 \mathrm{~mL}$, as shown in Fig. 4, the volumetric production of functional PLA1 was maintained consistently across the different reaction volumes examined $(150 \mu \mathrm{L}, 3$ and $500 \mathrm{~mL}$ ).

\section{Conclusions}

PLA1 has broad applications in diverse industrial sectors $[6,26]$. In this study, we demonstrated successful production of Serratia sp. PLA1 in a cell-free protein synthesis system. Compared to E. coli-based expression, where the production of this enzyme was hampered by damage to cell growth and extremely low levels of expression, efficient production of functional enzyme was achieved using cell-free protein synthesis. Furthermore, degumming of crude oil was successfully performed by the PLA1 synthesized from our cell-free protein synthesis system. Including the PLA1 investigated in this study, many industrial enzymes can interfere with the regular physiology of cells, making their production problematic. With the experimental results presented herewith, we believe that cell-free protein synthesis can be considered as a versatile option for rapid production of important 
a

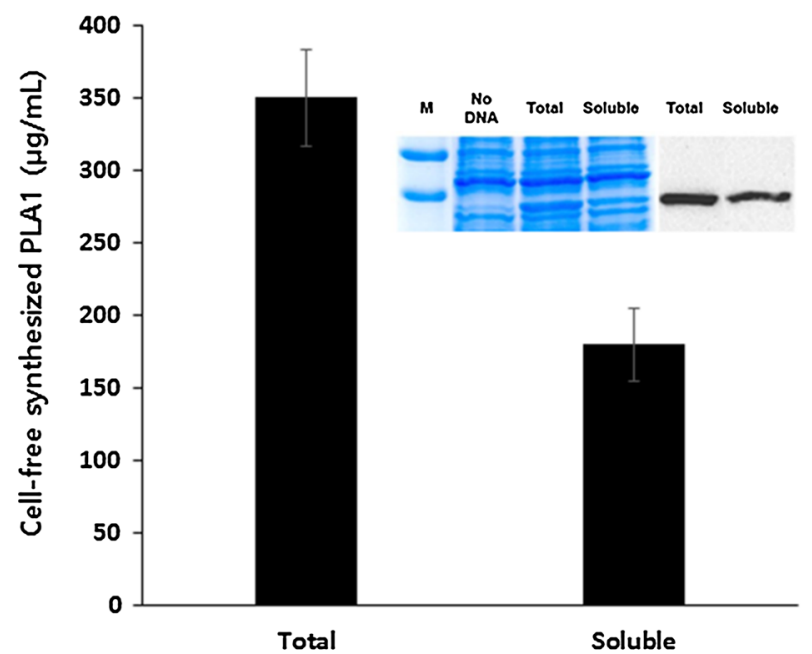

b

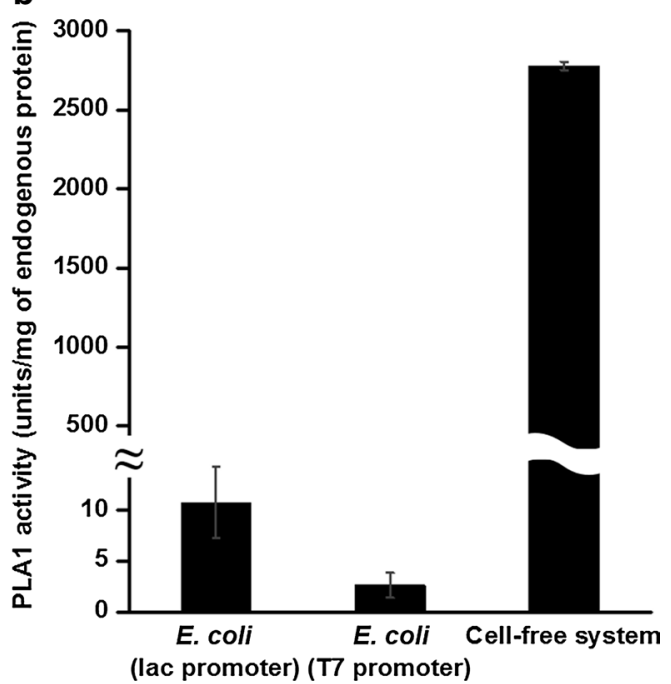

Fig. 2 Synthesis of PLA1 from Serratia sp. in a cell-free protein synthesis system. The plasmid pET21a Serr PLA1 was incubated in the reaction mixture for cell-free protein synthesis as described in "Methods" section. After incubation for $3 \mathrm{~h}$, total and soluble amounts of cell-free synthesized PLA1 were quantified by measuring the TCA-insoluble radioactivity of the samples (a). Embedded image of a shows the results of SDS-PAGE and western blot analysis. PLA1 activity produced per $\mathrm{mg}$ of endogenous cellular protein in E. coli or cell-free protein synthesis system was compared in $\mathbf{b}$

a

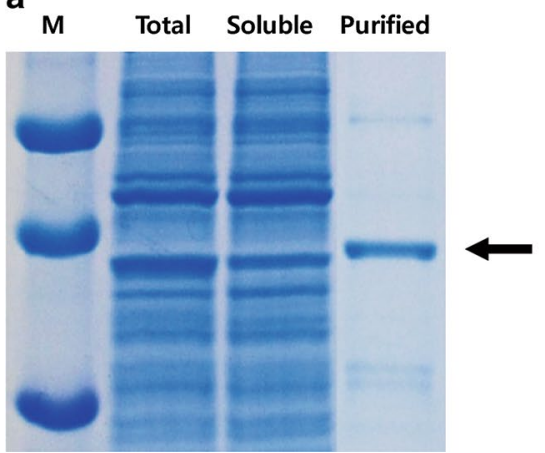

b

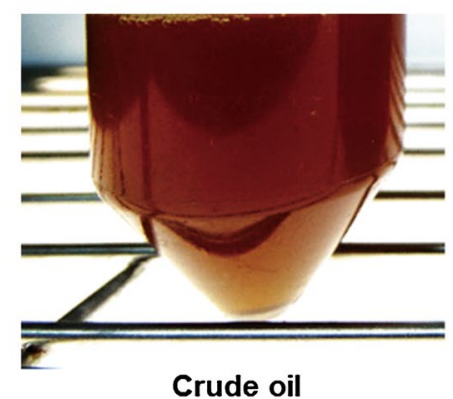

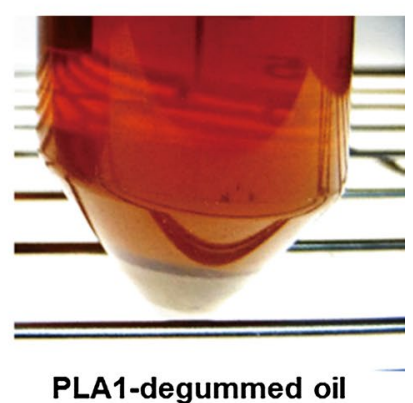

PLA1-degummed oil

Fig. 3 Purification of PLA1 expressed in each system. Cell-free synthesized PLA1 from a 3 mL reaction was purified through a Ni-NTA column (a). Turbidity of the crude sesame oil was cleared after incubation with the purified PLA1 ( $30 \mu \mathrm{g} P \mathrm{LA} 1 \mathrm{in} 10 \mathrm{~mL}$ oil) for $12 \mathrm{~h}$ at $40{ }^{\circ} \mathrm{C}$, indicating that the cell-free synthesized enzyme catalyzed degumming of crude oil (b)

Table 1 Gas chromatography analysis of crude sesame oil incubated with cell-free synthesized PLA1

\begin{tabular}{ll}
\hline $\begin{array}{l}\text { Amounts of } \\
\text { PLA1 }(\boldsymbol{\mu g})\end{array}$ & $\begin{array}{l}\text { Concentration of linoleic } \\
\text { acid in oil }(\mathbf{m M})\end{array}$ \\
\hline 0 & 8.7 \\
10 & 16.4 \\
20 & 21.0 \\
30 & 28.6 \\
\hline
\end{tabular}

$10 \mathrm{~mL}$ of crude sesame oil was incubated with varying amounts of cell-free synthesized PLA1 and analyzed as described in "Methods" section industrial biocatalysts. For now, the presented approach would be most ideal for high-speed screening and characterization of enzymes because the high cost of the reagents can limit its scale-up for industrial production. With the present composition of the reaction mixture for cell-free synthesis, $1 \mathrm{~mL}$ of reaction mixture costs approximately 3.5 USD. As demonstrated in Additional file 2: Figure S2, energy source, extract preparation and nucleotide triphosphate account for more than $80 \%$ of total reagent cost. Fortunately, it has been proven that the 


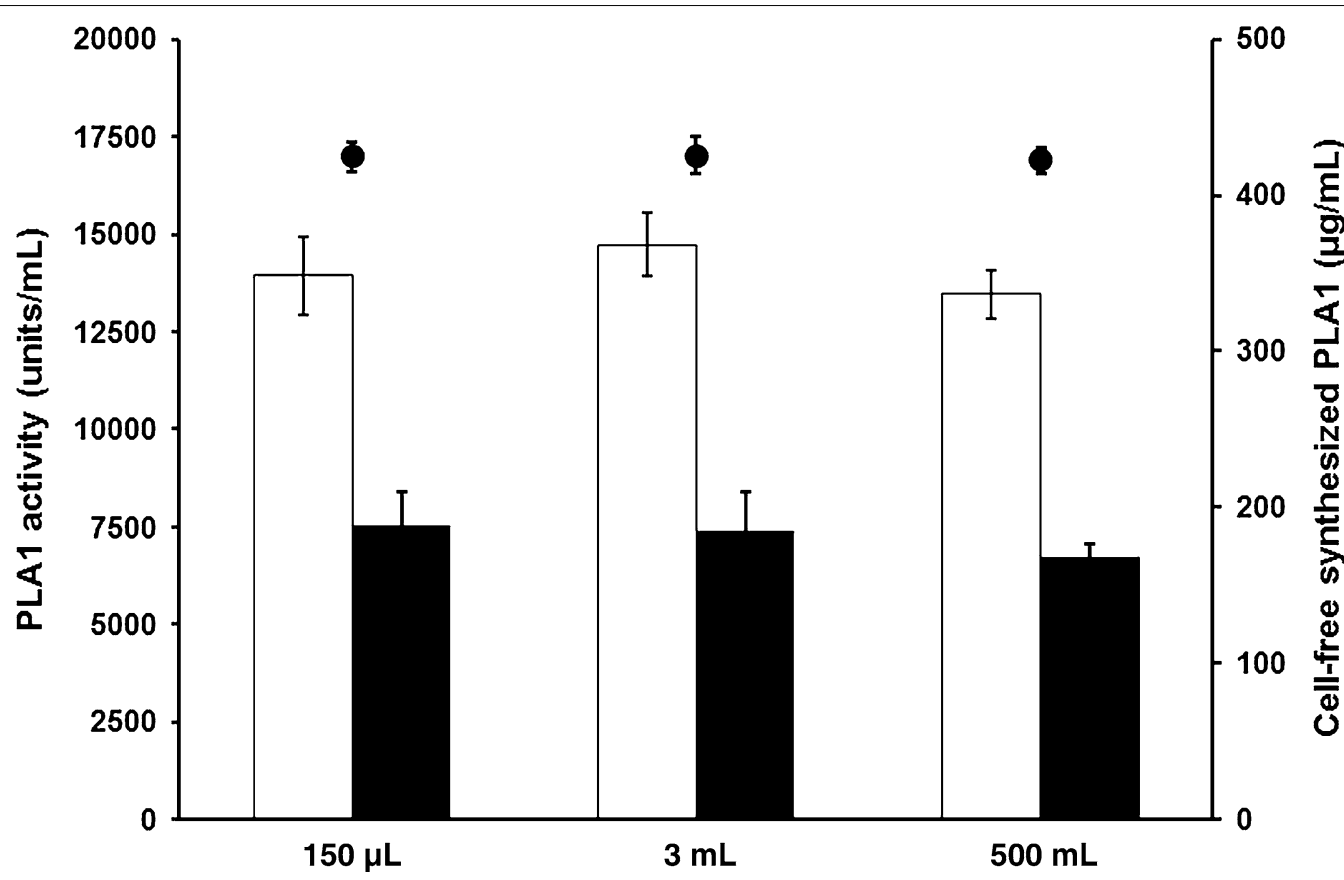

Fig. 4 Cell-free synthesis of PLA1 in varying reaction volumes. The reaction scale of cell-free PLA1 synthesis was increased sequentially from $150 \mu \mathrm{L}$ to $3 \mathrm{~mL}$ to $500 \mathrm{~mL}$. The total and soluble productivity and titer of functional PLA1 were not significantly affected by the reaction volume. The bars in the graph represent total (blank) and soluble (filled) amounts of cell-free synthesized protein. Circles represent PLA1 activity measured in the reaction mixture. Error bars represent the standard deviation from three independent experiments

costs for these components can be markedly reduced by the use of cheap energy sources (glucose, for example), preparation of cell extract after high-cell density culture of $E$. coli cells and use of NMP instead of NTP, respectively [27]. We thus expect that both the productivity and economics of cell-free synthesis of enzymes can be substantially improved for industrial applications in the near future.

\section{Additional files}

Additional file 1: Figure S1 Gas chromatography analysis of sesame oil incubated with cell-free synthesized PLA1.

Additional file 2: Figure S2. Analysis of reagents for cell-free protein synthesis.

\section{Abbreviations}

PLA1: phospholipase A1; LB: Luria-Bertani; IPTG: $\beta$-D-1-thiogalactopyranoside; Folinic acid: 1-5-formyl-5,6,7,8-tetrahydrofolic acid; TCA: trichloroacetic acid; PBS: phosphate buffered saline; Ni-NTA: nickel-nitrilotriacetic acid; RCF: relative centrifugal force; RPM: revolutions per minute; SDS-PAGE: sodium dodecyl sulfate-polyacrylamide gel electrophoresis; NMP: nucleotide monophosphate; NTP: nucleotide triphosphate.

\section{Authors' contributions}

HJL, JKS and DMK designed the experiments; YJP, HJL, YJJ, JEC, JYO and JHP performed the experiments; JKS and DMK supervised the work; HJL, JKS and DMK wrote the manuscript. All authors read and approved the final manuscript.

\section{Acknowledgements}

Not applicable.

\section{Competing interests}

The authors declare that they have no competing interests.

Availability of supporting data

Supporting data not available.

\section{Consent for publication}

The authors hereby consent to publication of this work in Biotechnology for Biofuels.

\section{Funding}

This work was funded by National Research Foundation of Korea (Grant numbers: 2014M3C1A3051473, 2015M3D3A1A01064878 and 2016M1A5A1027465).

Received: 27 April 2016 Accepted: 12 July 2016

Published online: 29 July 2016

\section{References}

1. Lin L, Cunshan Z, Vittayapadung S, Xiangqian S, Mingdong D. Opportunities and challenges for biodiesel fuel. Appl Energy. 2011;88(4):1020-31.

2. Galhardo F, Hitchman T. Has degumming with enzymes come of age. Oil Mil Gazetteer. 2012;117:1-5.

3. Borrelli GM, Trono D. Recombinant lipases and phospholipases and their use biocatalysts for industrial applications. Int J Mol Sci. 2015;16(9):20774-840.

4. Jang MG, Kim DK, Park SC, Lee JS, Kim SW. Biodiesel production from crude canola oil by two-step enzymatic processes. Renew Energy. 2012:42:99-104. 
5. Cesarini S, Haller RF, Diaz P, Nielsen PM. Combining phospholipases and a liquid lipase for one-step biodiesel production using crude oils. Biotechnol Biofuels. 2014;7(29):1-12.

6. De Maria L, Vind J, Oxenbøll KM, Svendsen A, Patkar S. Phospholipases and their industrial applications. Appl Microbiol Biotechnol. 2007;74:290-300.

7. Nielsen PM, Brast J, Fjerbaek L. Enzymatic biodiesel production: technical and economical considerations. Eur J Lipid Sci Technol. 2008;110(8):692-700.

8. Catherine C, Oh SJ, Lee KH, Min SE, Won JI, Yun H, Kim DM. Engineering thermal properties of elastin-like polypeptides by incorporation of unnatural amino acids in a cell-free protein synthesis system. Biotechnol Bioprocess Eng. 2015;20(3):417-22.

9. Kim TW, Keum JW, Oh IS, Choi CY, Park CG, Kim DM. Simple procedures for the construction of a robust and cost-effective cell-free protein synthesis system. J Biotechnol. 2006;126(4):554-61.

10. Kim MK, Rhee JS. Isolation of a phospholipase $A_{1}$-producing microorganism. J Ind Microbiol. 1996:16:171-4.

11. Oh SJ, Lee KH, Kim HC, Catherine C, Yun H, Kim DM. Translational incorporation of multiple unnatural amino acids in a cell-free protein synthesis system. Biotechnol Bioprocess Eng. 2014;19(3):426-32.

12. Amer B, Nebel C, Bertram HC, Mortensen G, Dalsgaard TK. Direct derivatization vs aqueous extraction methods of fecal free fatty acids for GC-MS analysis. Lipids. 2015;50:681-9.

13. Song JK, Kim MK, Rhee JS. Cloning and expression of the gene encoding phospholipase A from Serratia sp. MK1 in Escherichia coli. J Biotechnol. 1999;72(1-2):103-14

14. Song JK, Rhee JS. Simultaneous enhancement of thermostability and catalytic activity of phospholipase $A_{1}$ by evolutionary molecular engineering. Appl Environ Microbiol. 2000;66(3):890-4.

15. Song JK, Rhee JS. Enhancement of stability and activity of phospholipase $A_{1}$ in organic solvents by directed evolution. Biochim Biophys Acta. 2001:1547(2):370-8

16. Song JK, Chung B, Oh YH, Rhee JS. Construction of DNA-shuffled and incrementally truncated libraries by a mutagenic and unidirectional reassembly method: changing from a substrate specificity of phospholipase to that of lipase. Appl Environ Microbiol. 2002;68(12):6146-51.
17. Brunner M, Bujard H. Promoter recognition and promoter strength in the Escherichia coli system. EMBO J. 1987;6(10):3139-44.

18. Deuschlel U, Kammerer W, Gentz R, Bujard H. Promoters of Escherichia coli: a hierarchy of in vivo strength indicates alternate structures. EMBO J. 1986;11(5):2987-94

19. Jajesniak P, Wong TS. From genetic circuits to industrial-scale biomanufacturing: bacterial promoters as a cornerstone of biotechnology. AIMS Bioeng. 2015;2(3):277-96.

20. Rocha S, De Keersmaecker H, Hutchison JA, Vanhoorelbeke K, Martens JA, Hofkens J, Uji-i H. Membrane remodeling processes induced by phospholipase action. Langmuir. 2014;30:4743-51.

21. Wu EL, Fleming PJ, Yeom MS, Widmalm G, Klauda JB, Fleming KG, Im WE. coli outer membrane and interactions with OmpLA. Biophys J. 2014;106:2493-502.

22. Shimuta K, Ohnishi M, lyoda S, Gotoh N, Koizumi N, Watanabe H. The hemolytic and cytolytic activities of Serratia marcescens phospholipase A (Ph|A) depend on lysophospholipid production by PhIA. BMC Microbiol. 2009;9:261

23. Hou MH, Chuang CY, Ko TP, Hu NJ, Chou CC, Shih YP, Ho CL, Wang AH. Crystal structure of vespid phospholipase $\mathrm{A} 1$ reveals insights into the mechanism for cause of membrane dysfunction. Insect Biochem Mol Biol. 2016:68:79-88.

24. Takors R. Scale-up of microbial processes: impacts, tools and open questions. J Biotechnol. 2012;160:3-9.

25. Dudley QM, Karim AS, Jewett M. Cell-free metabolic engineering: biomanufacturing beyond the cell. Biotechnol J. 2015;10:69-82.

26. Hama S, Ogino C, Kondo A. Enzymatic synthesis and modification of structured phospholipids: recent advances in enzyme preparation and biocatalytic processes. Appl Microbiol Biotechnol. 2015:99(19):7879-91.

27. Zawada JF, Yin G, Steiner AR, Yang J, Naresh A, Roy SM, Gold DS, Heinsohn HG, Murray CJ. Microscale to manufacturing scale-up of cell-free cytokine production-a new approach for shortening protein production development timelines. Biotechnol Bioeng. 2011;108(7):1570-8.

\section{Submit your next manuscript to BioMed Central and we will help you at every step:}

- We accept pre-submission inquiries

- Our selector tool helps you to find the most relevant journal

- We provide round the clock customer support

- Convenient online submission

- Thorough peer review

- Inclusion in PubMed and all major indexing services

- Maximum visibility for your research

Submit your manuscript at www.biomedcentral.com/submit
O Biomed Central 